8 comunitania)

JULIO / 2014
REVISTA INTERNACIONAL DE TRABAJO SOCIAL Y CIENCIAS SOCIALES INTERNATIONAL JOURNAL OF SOCIAL WORK AND SOCIAL SCIENCES

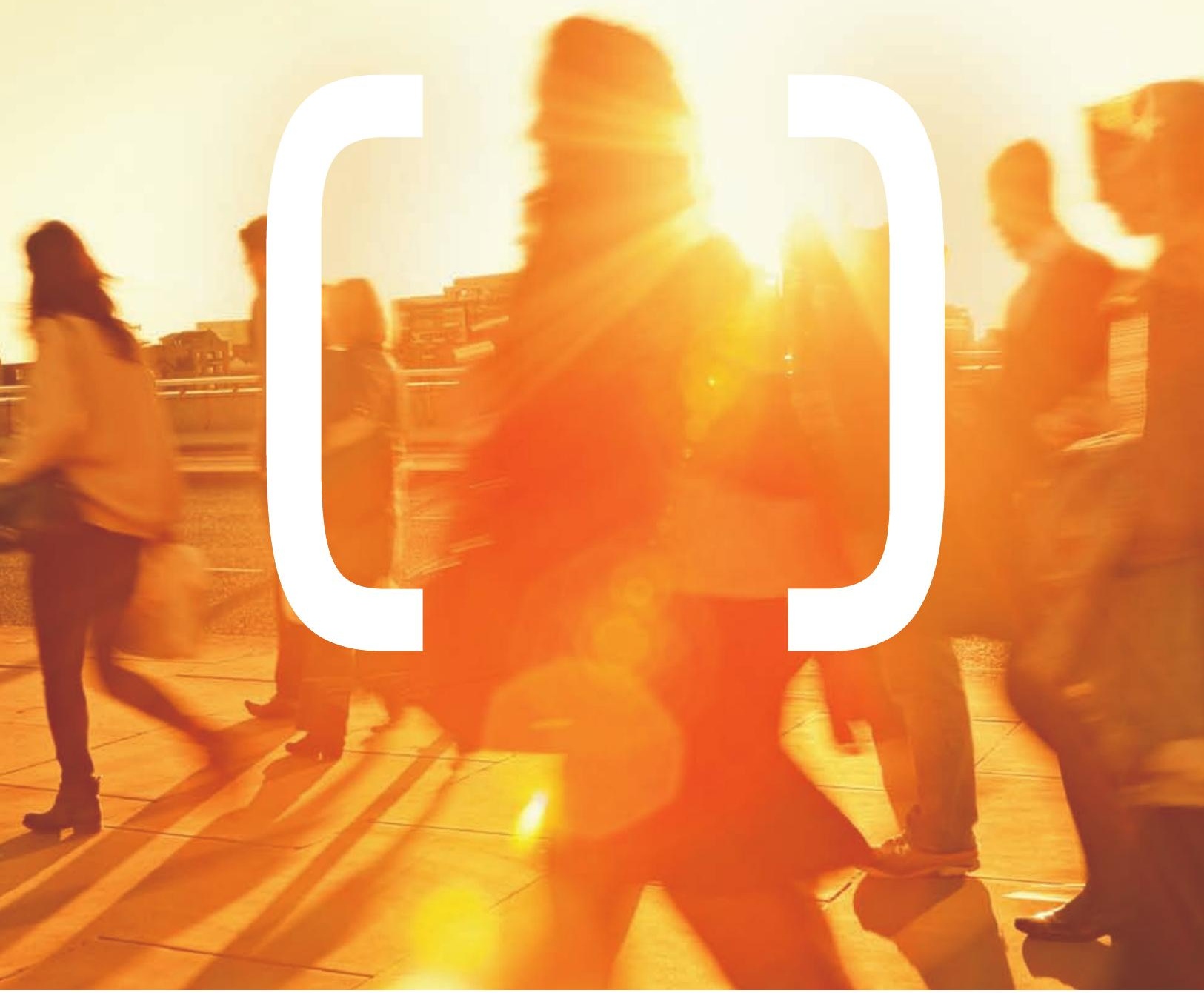

AURELIO TOMMASETTI | ORLANDO TROISI | SILVIA COSIMATO | FRANCESC XAVIER UCEDA I MAZA

MARÍA GARCÍA MUÑOZ | LUCÍA MARTÍNEZ MARTíNEZ | STELLA MARIS SEMINO | RICH FURMAN | MICHELLE D. ENTERLINE GREG LAMPHEAR | ALLISON E. SHUKRAFT | JOSÉ JAVIER NAVARRO PÉREZ | ELISEU V. MARTÍNEZ MUÑOZ | PILAR MONTESÓ-CURTO 


\title{
Meaning as A Core Principle in Social Work Practice El sentido como principio dásico en la práctica del Trabajo Social
}

\author{
Rich Furman”, Michelle D. Enterline**, Greg Lamphear ${ }^{* * *}$ y Allison E. Shukraft**** \\ ** Professor, Social Work, University of Washington Tacoma. rcfurman@u.washington.edu \\ ** Clinical Social Worker \\ *** Journalist and independent scholar \\ **** Pediatric Palliative Care Social Worker, Carolina Health Care System's Levin Children's Hospital
}

\begin{abstract}
Abstrac:
This paper explores the concept of meaning as a focus area for expanding core values and practice realities in social work. By focusing on helping clients develop a sense of meaning and purpose in their lives, social workers can help clients maximize their personal and cultural strengths in the service of meeting their developmental and social aims. A case example is used, and concepts discussed are applied in the area of finding meaning in life.
\end{abstract}

Keywords: Social work practice, meaning, existentialism.

\section{Resumen:}

En este trabajo se explora el concepto de significado como un área de interés para la expansión de los valores fundamentales y las realidades de la práctica en el trabajo social. Al centrarse en ayudar a los clientes a desarrollar un sentido de significado y propósito en sus vidas, los trabajadores sociales pueden ayudar a los clientes a maximizar sus fortalezas personales y culturales al servicio del cumplimiento de sus objetivos sociales y de desarrollo. Se utiliza un ejemplo de caso, y conceptos tratados se aplican en el ámbito de la búsqueda de sentido de la vida.

Palabras clave: la práctica del trabajo social, significado, existencialismo.

\section{Article info:}

Received: 11/06/2013 / Received in revised form: 13/06/2014

Accepted: 20/06/2014 / Published online: 20/07/2014

DOI: http://dx.doi.org/10.5944/comunitania.8.4

\section{Introduction}

In each era, certain concepts have become organizing principles that greatly influence social work practice. While some of these concepts have faded into history, 
some have had considerable lasting power. For instance, the notion of "starting where the client is" has held a central place in social work education and practice for nearly a century (Richmond, 1917; Taft, 1939). Since the 1960's, "empowerment" has been an influential principle that has driven culturally sensitive social work practice along the micro/macro continuum (Devore, \& Schlesinger, 1991; Saleebey, 2002). The exploration and expansion of these concepts has helped focus the profession on important values and skills that we require of practitioners. These concepts become the building blocks for practice wisdom that may inform social work practice perhaps even more than research or theory (Goldstein, 1999), and become woven into the fabric of the profession. Concepts imbedded into current practice wisdom become essential notions related to the human condition and focus practice interventions on resolving various social and psychosocial problems.

As the profession strives to contend with rapid transformations of the social order brought about by globalization (Furman, Puig, Szto, \& Langer, 2003; Healy, 2001; van Wormer, 1997), the advent of hyper technologies (Kreuger, 1997), the medicalization of social problems by managed behavioral health corporations (Furman, 2003; Furman, Downey, \& Jackson, 2004), as well as other complex problems of post-modernity, new concepts are needed to focus the profession on its core values and aims. While each of the above listed changes may lead to some positive developments, each may also lead to the marginalization of vulnerable populations and a focus away from time-tested social work values. In response, additional concepts are needed to guide social workers in their efforts to maximize human strength, potential and resiliency in the face of these large scale global shifts. Concepts are needed that help re-humanize the profession of social work and help individuals, families and small groups develop satisfying ways of living.

The purpose of the paper is to explore the concept of meaning as one concept that can focus the profession on key core values and practice realities. While the concept of meaning has been integral to several theories of social work and the disciplines that inform it (Maluccio, 1981; Pray, 1949; Rank, 1945), it has not been advocated as a central practice notion. This is lamentable, as the search for meaning is one of the key driving force in each of our lives (King, 2004; Phillips, 1999; Reker, Peacock, \& Wong, 1987; Thompson et. al., 2003). Meaning is an important psychological component in the promotion of individual well-being. Indeed, the search for meaning may actually be an innate drive (Krill, 1986) or a central motivation for survival (Ai, Cascio, Santangelo, \& Evans-Campbell, 2005). By focusing on helping clients develop a sense of meaning and purpose in their lives, social workers can help clients maximize their personal and cultural strengths in the service of meeting their developmental and social aims.

\section{Roots of the Notion of Meaning}

The perspective that perhaps most directly and thoroughly addresses the issue of meaning is existentialism. The most fundamental aim of existentialism is defining or 
finding meaning in life. The search for meaning in life is associated with freedom; freedom to choose one's one thoughts, beliefs, and perspective. Existentialism maintains no "absolute truth"; it instead adheres to the "subjective truth" of the individual, free of absolutes. Although one's subjective truth is most certainly influenced by history, culture, and social institutions, it is still the individual's own personal interpretations of these that allow him or her to find and achieve meaning (King \& Hicks, 2009).

Based upon a philosophical lineage beginning with the ancient Greeks, through Kierkegaard and Nietzsche in the $19^{\text {th }}$ century, to Jaspers, Sartre, and Heidegger in the $20^{\text {th }}$ century, existentialism has had a profound impact upon psychology, the helping professions, and to a lesser degree social work (Furman, 2007). Jaspers (1951) contended that the phenomena of mass production and consumption and the development of machination and industrialization produced a mass man; a human being void of individuality, whose life lacked a sense of purpose and meaning. To Sartre (1956) the most basic dilemma of human existence is centered upon notions of meaning and meaninglessness.

Meaning, and a person's ability to construct a meaningful life, lies at the center of the human quest (Bugental, 1978). People are thought to possess the capacity for creating meaning and fulfillment even within the direst social contexts. Likewise, when meaning is recognized in positive experiences, it can foster one's ability to detect and construct meaning and increase positive effect, which has been positively correlated to one's ability to find meaning (King \& Hicks, 2009).

Frankl (1963) noted that even those living in Nazi concentrations camps were often able to establish a sense of meaning. Many of the people imprisoned were able to survive the extreme hardships of the camps, and find some way of placing their suffering into perspective and establishing personal meaning out of their suffering. Frankl's own experience in the camps inspired his belief that individuals are motivated to find personal meaning, to make sense of their lives and to feel that life itself is significant, important, worthwhile, or purposeful (Morgan \& Farsides, 2009). Indeed, existentialists believe that each person possesses the capacity to create a meaningful, worthwhile existence in spite of not only external circumstances, but of painful pasts as well. In this manner, how we find meaning in our lives, as well as the meaning we find, is formed and reformed based on our experiences (King, 2004). Meaning exists when a person feels that an event "makes sense," and fits with one's existing beliefs and expectations (King \& Hicks, 2009). Meaningfulness may come from a sense that events are on the whole significant, profound or endorse a feeling of rising above the humdrum aspects of life (Leontiev, 2005, as cited by King \& Hicks, 2009).

Yet, philosophy is not the only discipline to have explored the notion of meaning. With the advent of Newtonian physics, and the revelation that exact laws could pre- 
dict the movement of physical bodies, the nature of existence and the meaning of life became increasingly the domain of the scientist (Rosenberg, 2000). This trend accelerated after Darwin's revolutionary theories were developed in the mid $19^{\text {th }}$ century, as evolutionary explanations challenged the notion of a grand plan created by a grand planner. This notion of a sense of meaning and purpose in life apart from theistic explanation gave further credence for alternative explanations for meaning and purpose to existence.

Additionally, meaning has been a recurring topic throughout literary history as well. Shakespeare's characters focused on the search for meaning-often willing to give up their lives to live significant and authentic lives. Romeo and Juliet sacrificed themselves for love that they believed was their sole purpose in life. Macbeth squandered friendships and lives in order to die in his quest for power. Hamlet often wondered what purpose remained in his life after the death of his father, only to die in his quest for revenge over his father's murder.

Modern literature often tackles this concept as well. In The Chess Garden, by Brooks Hanson, the main character Dr. Gustav Uyterhoeven sends a series of mysterious letters home to his wife from his work during South Africa's Boer Wars. In the letters he draws the entire town in with fantastic tales of his travels in a world populated by game pieces and mysterious dark forces. The letters become a uniting force for the small town, serving as a weekly meeting, and filling them with a mystery that gets them all talking. In the end, it is revealed that the dark force haunting the doctor's world is his own death, and we come to realize that the letters were his effort not only to find meaning in his own death, but to help his wife and friends do so as well.

So with all of these great thinkers putting their hand in the creation of meaning, what definition can we come to for meaning itself? Frankl (1969) posits three domains in which man/womankind can achieve meaning: in the realm of the physical world; in the realm of the social world; and in the realm of one's inner world. In this way, we find meaning in how we encounter nature and the world around us, how we interact with others, and how we interact with ourselves. This idea is in line with King's (2004) idea of meaning being guided by experiences. Although we may come to one idea about what is important or purposeful in our lives, these ideas often shift with time, maturity, and experiences, if we pay attention to the consequences, both positive and negative, of these experiences and how they worked out for us. Meaning is connected to life stages and is personally constructed according to life experiences. The fact that the absence of meaning is a noticeable loss suggests that meaning was present at one time but may have been taken for granted. King and associates note that meaning in life is not just an overarching conclusion made about life as a whole, but an ambient aspect of daily life. They posit that a meaningful life is purely a collection of meaningful days or the experience of daily meaning may be "a global sense of meaning in life that adds a 'glow' 
of meaning to judgments about specific life domains" (King, Hicks, Krull, \& Del Gaiso, 2006).

\section{The Role of Spirituality in Creating Meaning}

One of the most obvious connections associated with the search for meaning is spirituality. As social workers, we must be cognizant of the fact that to some clients, meaning and spirituality or religion are closely connected, as a part of their culture or upbringing. For others, discovering meaning in life is not associated with a religious experience, but to some degree it may be spiritual. For the sake of distinction between spirituality and religion, it is assumed here that religion is connection to a formal institution, whereas spirituality is not. Both spirituality and religion may focus on the sacred, a higher power, or individually perceived higher power. To be clear, the authors here intend to explore the concept of spirituality, rather than the concept of religion.

In their research into hope and meaning following the 9-11 attacks, $\mathrm{Ai}$, Cascio, Santangelo, \& Evans-Campbell, (2005) note that spiritual meaning does not need to be religious in nature, but can come from "various means, including science, power, nonspiritual or spiritual modeling, nonpolitical or political actions, environment, or historically striking events. Canda (1999) states that taking a spiritual approach to social work means allowing the client to form their own search for purpose and morality in their own way of understanding. In this way, social workers should have a bio-psycho-social-spiritual approach to practice in order to "make room" for the role of spirituality in the clients lives. It is a fundamental aspect of the client and who he sees himself to be. Additionally, Canda cites, this aspect of a person is part of how we relate to the greater world around us. Other people, the world, nature, a higher power, however individuals define this, their own personal spirituality is how they feel connected to the world as a whole.

This connection has been noted by other theorists as well. Frankl (1963) posited that humans are in their own in the world. No God, no authority, no power can be relied upon by the individual and magically teach him/her the meaning of life. Human beings are condemned to freedom, in that they must create their own meaning and way of life. However, this freedom is painful and causes anxiety, which can be courageously faced or tuned out through addictions, blind obedience or other "bad faith" strategies that numb these existential pangs. Freedom, and the willingness to face it, is both a liberation and a burden (Thompson, 1992). These factors both demand and impair our ability to find meaning. We are simultaneously compelled to make sense and order of our existences through finding personal meaning yet are frozen by the terror and dread of the difficulty of this lonely, arduous quest.

Meaning can come from establishing for oneself a connection to some larger picture or purpose, such as religion or philosophy, or even history (ancestry and one's 
place in it). When thinking of life in this broad context, people are likely to see how their daily lives fit into the whole picture of their lives, or even greater, into the whole puzzle of being. This helps us to see the grand scale of life as something that we may one day understand (King, Hicks, Krull, \& Del Gaiso, 2006).

The importance of spirituality to human well-beings has been gaining growing attention in social work. Increasingly, spirituality is being included in assessments, with proponents arguing for a bio/psycho/social/spiritual conception of human existence. While conceptions of spirituality differ, many directly relate to the concepts of meaning and purpose. Hicks (1999), for example, defines spirituality as a set of dynamic principles that one develops throughout the lifespan that helps nurture and guide a person's view of the world, influence the interpretation of hopes, fears, morals, loss, faith and trust as well as provide a structure to everyday activities. According to Swinton (2001), spirituality:

strives to answer deep existential questions pertaining to the meaning of life, suffering, illness and so forth, as well as recognizing the need for human interconnectivity and the desire to transcend the self in meaningful ways (p.23).

In this sense, the search for meaning serves to carry people through the difficult tasks and experiences in their lives. With the addition of spirituality to the mix, most major religions provide guides when something happens to make one question meaning and order. Through text and spiritual leaders, an explanation, a purpose can often be found for negative experiences, which can serve to help the individual to continue on with his life.

However, finding meaning, even spiritual meaning, can connect people without a religious base. Clients may struggle with the concept of spirituality and religion as a basis for finding meaning in their lives. One example of this struggle is writer and performer, Julia Sweeney, who started out on a quest for spirituality. Her search ended with her decision to become an atheist. After broadcasting on Public Radio International, she found that others could relate to her story, and she was able to connect to them through her show and website (Burton, 2008). This is an example of how a client's path of self exploration can lead them to their own individual truth.

\section{The Role of Personal Meaning in Social Work}

Based upon empirical research into the experience of the disabled, King et. al. (2003) postulate that people draw meaning from three potential areas in life: through their sense of belonging or interconnectedness to the world of others; through certain activities; or, through their understanding of their own nature and the world around them. In a later work, King (2004) explores the importance of helping people focus on developing meaning in life, as opposed to the meaning of 
life, thereby helping people to pay attention to the development of a personally constructed meaning that can be life enhancing. Stated simply, if the client establishes their own meaning or purpose, he is more likely to "buy" it. Without client buy-in, there will be little value to the work that he does with the social worker. Thus, she can be there to help her client in the search for this meaning, but cannot be the one to assign it, as this would remove all value from the exercise.

Frankl (1984) suggested that meaning can be achieved through personal accomplishments (goal attainment), encounters with others or encounters with art or nature (connection). He also noted that meaning is always present, to be detected rather than invented by individuals. Baumeister (1991) contended that finding meaning in life is dependent upon fulfillment of four psychological needs: purpose, value, efficacy and self worth. The experience of finding meaning may indeed be at times detected, and at other times be constructed.

Keen (1992) recounts a story that appropriately places the role of meaning and purpose. During a time of crisis, he seeks the counsel of a friend/mentor. Over a drink, his friend informs him that there are two questions a man (and presumably a woman) must ask himself: "Where am I going?" and "Who is going with me?" He was also told that if he got the order of these two questions reversed, trouble would be the consequence.

Possessing a sense of purpose in life is a powerful resiliency factor. Life, by its inherent nature, is challenging. Much of the practice of positive mental health involves dealing with and managing anxiety. The role of the social worker, in times of crisis, as well as in times of calm, is to help manage anxiety, whether it arises in dealing with meeting the client's basic needs, his mental health, his adaptation to a new situation, or his facing up to addiction. The quest for meaning within day-to-day life can help with the management of anxiety. In this way, the quest for personal meaning needs to follow a lifespan perspective. Experiences in life change the way that people view their purpose, and, as new experiences occur, they may bring about a shift in the individual's paradigm of her own meaning (King, 2004). Often, research focuses on turning points or traumatic events in a person's life as the essential time in which to develop meaning. But, following King's model, meaning is fluid, happening on more than one level and in more than one way at any given time. Though a large event in someone's life may cause her to question the meaning of life or her purpose in it at that time, it is important that she have a foundation from which to draw.

Attitude has been found to have a profound effect on the discovery or construction of meaning. Frederickson $(1998,2001,2002)$ posits in his broaden-and-build theory that positive emotions expand a person's "momentary-thought-action repertoire." Frederickson's positive emotion theory is empirically supported by a number of studies. Isen and colleagues found that positive emotions assist people 
with creative problem solving, position them to be more open to new information processing and provides greater cognitive flexibility (Isen, 1999). In addition, research shows that positive emotions influence cognitive and attentive processes, which are characterized by a global rather than local focus (Frederickson \& Branigan, 2004). This concept suggests that positive emotions assist in broadening the scope of attention, which can be helpful to many clients (Frederickson, 2003).

The role of negative mood on finding meaning is outlined by King and her colleagues. In a study of the effects of positive emotions, implications for better understanding the relationship of negative mood and finding meaning in life were discovered (King, et al, 2006). As may be expected, negative attitude adversely affected the meaning experience. Cognitive effects of negative attitude constricts analytical focus and attention, reducing the global sense of meaningfulness, but may be useful in searching for meaning in experiences in life that cultivate negative mood (King, 2006). King suggests that positive attitude may assist in more abstract, top-down answers to finding meaning, while negative attitude may be central to the bottomup struggle that may illustrate coping with situations in preexisting structures of meaning that are not understood by the person (King, 2006). If a person defines meaning as having the sense of her or his place in a grander scheme, positive attitude can be an important factor. If a person characterizes meaning by finding lessons in past experiences, negative attitude may play a greater role (King, 2006).

\section{Practice Implications of the Importance of Meaning}

This section explores social work practice implications of the importance of the role of meaning in the lives of clients. The trend in social work and other helping professions has been towards evidenced-based practice that focuses on specific symptoms that provide the focus for treatment (Furman, 2009). It began with development of behavioral oriented theories and practice such as the problem solving approach, and has gained considerable adherence with the increasing influence of logical positivism and the advent of managed care. Yet, there are risks in focusing only upon measurable symptoms in clinical practice. Take for example a client who presents for treatment of depression. Evidenced based practice would support the choice of cognitive therapy and/or medication to ameliorate their depressogenic symptoms. Once the symptoms have been alleviated, the client's treatment would be deemed a success and they would be discharged from practice. Yet, the client may still not have developed a coherent sense of meaning and purpose in their life and thus may be susceptible to depression.

Most research into the arena of meaning focuses on meaning and its impact on people when they have negative experiences. Some researchers have found that meaning comes from a sense that one's life is coherent, which will not be the case in crisis (King, Hicks, Krull, \& Del Gaiso, 2006). So the question becomes, how can 
social workers establish coherence in our everyday practice, and foster this in our clients as well? This would shift our practice from being pathology-based to a preventative, strengths-based approach practice. Although it is helpful to be able to find meaning in times of stress, it is even more important to foster that search for meaning in everyday life. This can help clients bolster their internal resources and be able to determine their own strengths. This way, when life gets difficult, as it does from time to time, individuals and families are better equipped to deal with life in general, and to gain something out of it, rather than simply get through each crisis as it comes to them.

Connection to others is also of importance when examining the role of meaning in social work. Canda (1999) states that social work has become disconnected from its spiritual roots. He states that spirituality "involves understanding the interconnectedness of all people; compassionate concern rises from soulful awareness of interconnectedness and the realization that self and others are inseparable" (Canda, 1999). He encourages a recovery of spirituality into practices because it fosters this interconnectedness, including communication and a sense of mutual responsibility.

Putnam (2000) also delves in to the realm of social connectedness through his examination of the decline of social capital within the modern United States. Although the detriments of declining social capital are myriad on a macro-level, they also affect people on an individual level as well. Specifically, the act of being connected, something which King (2004) notes is connected to purpose and happiness, is, according to Putnam, essential to health and happiness. According to Putnam's research, "people who are socially disconnected are between two and five times more likely to die from all causes" (Putnam, 2000, p 327).

\section{Case example}

Jessica, a married high school teacher with two children in college had been married for 25 years when she found that her husband had cancer, and was given a prognosis of 6 months to one year to live. Although they had struggled through parts of their marriage, they had been partners for more than half of her lifetime and she relied on his companionship, especially since they had recently moved to a new town to accommodate his job.

During his illness, though Jessica spent much of her time caring for her husband, he made it clear to his family that he wanted them to continue on with their lives. Though he wanted to spend time with them and to "settle up" with each of them, he also wanted them to learn to live without him, as that was a reality that they would be dealing with. For Jessica, this meant building her own community of support. She began making friends at her new job and communicated with them early on about what was going on in her life. In this way, she had not only the support of their long- 
term friends in the form of long visits and phone support, but she also, slowly, began to grow a support system within the area which could help meet her more basic needs, such as bringing in food and providing respite. A local hospice served much of this function. After her husband passed, though she had wide sweeping support from her old friends, her local support system was more based in the hospice program. She relied on support groups and grief counselors at first. With time though, she was ready to get out and gradually become a part of the community.

\subsection{Application of the Theories Presented to Case Example}

How did Jessica find meaning in the throes of her husband's illness and resulting death? Negative life events, such as the death of a loved one, may be seen as contradictory with one's core assumptions about the world before the event, and inhibit the application of sources of meaning that were in place prior to the event. Lack of comfort afforded by these prior sources of meaning may prompt Jessica to begin a search for different sources of meaning. Jessica's process of building a community of support outside of her relationship with her husband may provide meaning in and of itself. The resulting meaning from seeking support outside of her husband is an accomplishment, her newly found meaning is shaped or earned, involving "awareness and intentional and effortful processing" (King \& Hicks, 2009). Her conscious awareness of the gap between experience (her husband's early death) and expectation (that he would live forever, or at least longer) may be a source of motivation to construct meaning in building a new support system. Constructing meaning as a coping mechanism during and after a negative life event serves a critical purpose in the grief process. Coping with adversity may be seen as a developmental opportunity, to revise pre-existing structures of meaning in order to accommodate one's reality (King \& Hicks, 2009) as in Jessica's case.

Jessica's experience may have tested her belief system. We don't know about Jessica's source of spirituality, or if one exists. From a spiritual standpoint, she may question elements of her belief system and their role in the experience of meaning during her crisis. In time, she may find meaning in the loss of her husband, perhaps gaining a deeper understanding of her own vulnerability, the importance of human relationships, and how fragile that meaning truly is. She may call upon her connection to a higher power as a source of comfort. In this broader context, Jessica may be able to make sense of the loss of her husband and how his death fits into the grander scale of life. She may realize that the sources of meaning she had previously, such as spirituality or religious faith, are still applicable, but in ways that are more clear for her (King \& Hicks, 2009). Social Workers need to be prepared for whatever form of spirituality or connection the client has, in order to best support and assist them.

Given the fact that Jessica was able to heed her husband's wish and advice to "build her own life" outside of him and seek outside support suggests that Jessica 
probably possesses a positive attitude, in spite of the dire situation she was facing. As stated earlier, positive emotions help in broadening the scope of a person's attention, allowing for more creative problem solving and putting them in a better position to be more open to new information processing and greater cognitive flexibility (Frederickson \& Branigan, 2004, Frederickson, 2003).

\section{Conclusion}

Meaning in life is not something that can be operationalized, per say, because it has different meaning to each individual. It is meaningful to people only when they ascribe meaning to it, and usually in the context of their concept of a greater picture (King, Hicks, Krull, \& Del Gaiso, 2006). It helps them to understand a reason for why they are here. It is immaterial whether this reason is of their own creation or is a genuine, universal truth, but it matters that each individual "buy it". The process of creating meaning, however, is something concrete that social workers can and should play a role in.

Meaning is something that individuals can create every day. It is guided by what they see and do, and how they interact with everything and everyone around them, and serves to guide their future choices. Only through a conscious effort can social workers help their clients to fuse all of these complex interactions together so that clients can determine what their meaning is and how to use this knowledge in a constructive way within their lives. From many of the theories discussed in this article, it would appear that most people believe that the true way to find meaning is to face adversity and overcome it. For many people who feel they do not have the internal resources to do this, the purpose of the social worker is to shine a light on these internal resources and work with the consumer at all times to help him see that he can get up when life puts him on the floor, he can stand strong, and, eventually, he will walk again.

\section{References}

Ai, A., Cascio, T., Santangelo, L., \& Evans-Campbell, T. 2005. "Hope, meaning, and growth following the September 11, 2001 Terrorist Attacks." Journal of Interpersonal Violence, 20, 523-548. Retrieved on April 11, 2007 from http://jiv.sagepub.com.

Bugental, J. F. 1978. Psychotherapy and process: The fundamentals of an existentialhumanistic approach. New York: Random House.

Burton, M. (Producer), \& Sweeney, J. (Director). 2008 Letting go of God [Motion picture]. United States: Five Sisters Productions.

Canda, E. R. 1999. "Spiritually sensitive social work: Key concepts and ideals. Journal of Social Work Theory and Practice" 1(1), 1-15. Retrieved on April 11, 2007 from http://www.bemidjistate.edu/sw_journal/issue01/articles/canda.html. 
Devore, W., \& Schlesinger, E. G. 1991. Ethic-sensitive social work practice. New York: Macmillan Publishing Company.

Frankl, V. 1963). Man's search for meaning: An introduction to logotherapy. New York: Pocket Books.

Furman, R. 2003. "Frameworks for understanding value discrepancies and ethical dilemmas in managed mental health for social work in the United States" International Social Work, 46(1), 37-52.

Furman, R. 2007. "Poetry and narrative as qualitative data and therapy: Explorations Into existential theory". Indo-Pacific Journal of Phenomenology 7(1),http://www.ipjp.org/issues/ may2007/Richard_Furman_7e1.pdf

Furman, R. 2009. "Ethical considerations of evidence-based practice". Social Work, 54(1), 82-84.

Furman, R., Downey, E. P. \& Jackson, R. L. 2004. “Exploring the ethics of treatments for depression: The ethics of care perspective." Smith College Studies in Social Work, 74(3), 125-138.

Furman, R., \& Puig, M., Szto, P., \& Langer, C. 2003. "Infusing international content in the social work education curriculum." Currents: New Scholarship in Human Services 2(2), http://fsw.ucalgary.ca/currents/articles/articles/rich_furman/index.htm

Goldstein, H. 1999. "The limits and art of understanding in social work practice". Families in Society, 80(4), 385-395.

Healy, L. M. 2001. International social work: Professional action in an interdependent world. New York: Oxford University Press.

Hicks, T. J. 1999. "Spirituality and the elderly". Geriatric Nursing 20(3): 144-146.

Hicks, J.A., Cicero, D.C. Trent, J., Burton, C.M. \& King, L.A. 2010. "Positive affect, intuition, and feeling of meaning." Personality Processes and Individual Differences 98(6), 967-979.

Keen, S. 1992. Fire in the belly. New York: Bantom.

King, G. A. 2004. "The meaning of life experiences: Application of a meta-model to rehabilitation sciences and services". American Journal of Orthopsychiatry 74(1), 72-88.

King, G., Cathers, T., Brown, E., Specht, J. A., Willoughby, C., \& Miller Polgar, J. 2003. "Turning points and protective processes in the lives of people with chronic disabilities". Qualitative Health Research 13(2), 184-206.

King, L. \& Hicks, J. 2009. "Detecting and constructing meaning in life events". The Journal of Positive Psychology 4(5), 317-330.

King, L., Hicks, J., Krull, J., \& Del Gaiso, A. 2006. "Positive affect and the experience of meaning in life". Journal of Personality and Social Psychology 90(1), 179-196.

Krill, D. 1986. The beat worker: Humanizing social work and psychotherapy practice. Lanham, MD: University of America Press.

Kreuger, L. W. 1997. "The end of social work". Journal of Social Work Education. 33(1), 19-27.

Maluccio, A. N. 1981. Promoting competence in clients. New York: The Free Press.

Morgan, J., Farsides, T. 2009. "Measuring meaning in life". Journal of Happiness Studies. 10, 197-214.

Phillips, J. 1999. "The hermeneutic critique of cognitive psychology". Philosophy, Psychiatry, \& Psychology 6(4), 259-264. 
Pray, K. L. M. 1949. Social work in a revolutionary age and other papers. Philade/phia:The University of Pennsylvania Press.

Putnam, R. 2000. Bowling Alone: The Collapse and Revival of American Community. New York: Simon and Schuster.

Rank, O. 1945. Will therapy and truth and reality. New York: Knopf.

Reker, G. T., Peacock, E. J., \& Wong, P.T. P. 1987. "Meaning and purpose in life and wellbeing: A life-span perspective". Journal of Gerontology 42(1), 44-49.

Richmond, M. 1917. Social diagnosis. New York: Russell Sage Foundation.

Rosenberg, A. 2000. Philosophy of science: A contemporary introduction. New York: Routledge.

Salebey, D. 2000. The strengths perspective in social work. Boston: Allyn and Bacon.

Sartre, J. P. 1956. Being and nothingness. New York: Philosophical Library.

Taft, J. 1939. A conception of the growth process underlining social casework practice. Social Casework October, 72-80.

Thompson, N. 1992. Existentialism and social work. London: Aldershot, Hants, \& Avebury. Thompson, N. J., Coker, J., Krause, J. S., \& Henry, E. 2003. "Purpose in life as a mediator of adjustment after spinal cord injury". Rehabilitation Psychology 48(2), 100-108.

van Wormer, K. 1997. Social welfare: A world view. Chicago: Nelson-Hall. 



\section{ARTICULOS/ARTICLES}

Patient Empowerment and Health online Community: two ways to give the new viability doctor-patient relationship / Cooperación y intercambio de conocimiento en la era de Internet: dos maneras de dar nueva viabilidad a la relación médico-paciente Aurelio Tommasetti, Orlando Troisi y Silvia Cosimato

El territorio y la intervención comunitaria con Adolescentes en Conflicto con la Ley. El Caso del Municipio de Burjassot / The territory and the community intervention with teenagers in conflict with law. The case of Burjassot

Francesc Xavier Uceda i Maza, María García Muñoz y Lucía Martínez Martínez

Págs 25-52

The role of Organised Civil Society in the reduction of social risks: How inequality intervenes in civil society actors' attitudes to co-engagement with migrant citizens in public and community life / El papel de la sociedad civil organizada en la reducción de los riesgos sociales: ¿Cómo la desigualdad interviene en las actitudes de los actores de la sociedad civil hacia el compromiso con los ciudadanos inmigrantes en la vida pública y de la comunidad?

Stella Maris Semino

Meaning as A Core Principle in Social Work Practice / El sentido como principio básico en la práctica del Trabajo Social

Rich Furman, Michelle D. Enterline, Greg Lamphear y Allison E. Shukraft

Trabajo Social Comunitario y Formación en Centros de Trabajo: una propuesta para la inserción de adolescentes problematizados desde la Educación Formal / Social Work Community and Work Training Centers: a proposal for insert troubled adolescents from the Formal Education José Javier Navarro Pérez y Eliseu V. Martínez Muñoz

La construcción de los roles de género y su relación con el estrés crónico y la depresión en las mujeres / The construction of gender roles and their relation to chronic stress and depression in women

Pilar Montesó-Curto

\section{RESEIIAS/REVIEWS}

Almudena Moreno Mínguez (editor). Family Well-Being. European Perspectives / Bienestar Familiar. Perspectivas Europeas, 2013. New York: Springer

(por Emilio Díaz de Mera)

M. Castro Guzmán, J. C. Chávez Carapia y Silvia Vázquez González. Epistemología y Trabajo Social, Tomo I / Epistemology and Social Work, Vol. 1, 2013. Méjico: Conacyt y Acanits (por Paloma Serrano Postigo)

Leticia Cano (coord.). Pobreza y Desigualdad Social. Retos para la reconfiguración de la política social / Poverty and Social Inequality. Challenges for the reconfiguration of social policy, 2013. México DF: Díaz de Santos, Ediciones y UNAM 